\title{
HUBUNGAN POLA MAKAN DAN AKTIVITAS FISIK DENGAN STATUS GIZI SISWI KELAS VII SMP NEGERI (FULL DAY SCHOOL)
}

\author{
Oleh: \\ Septa Katmawanti ${ }^{1}$, Supriyadi ${ }^{1}$, Inung Setyorini ${ }^{1}$, \\ 123 jurusan Ilmu Kesehatan Masyarakat, Fakultas Ilmu Keolahragaan \\ Universitas Negeri Malang \\ e-mail: inungsetyorini97@gmail.com
}

\begin{abstract}
The government's effort to improved the quality of education is through full day school program. Full day school starts in the morning until the afternoon. A relatively long time requires the students to follow all the learning activities in the school, resulting in the activities of the students become dense so that it affects the difficulties of students in setting the time of rest and pattern of eating.An irregular diet can have an impact on the nutritional status of schoolgirls.This research was conducted to know the relationship of dietaryhabit and physical activity with the nutritional status of Class VII SMP Negeri full day school, Malang. The draft on this study uses correlational research methods with a cross sectional research design. Samples used as many as 100 girls with stratified random sampling technique.Data analysis using Spearman correlation test. The results of this study showed a significant link between dietary habit and nutritional status of studentswith $P$ value 0.000 and correlation coefficient of 0.406.Also indicates a significant relationship between physical activity and nutritional status of studentwith $P$ value 0.000 and correlation coefficient of- 0.348
\end{abstract}

Keywords: dietary habit, physical activity, nutritional status

\begin{abstract}
Abstrak: Upaya pemerintah dalam meningkatkan mutu pendidikan salah satunya adalah melalui program full day school. Full day school dimulai pada pagi hari hingga sore hari. Waktu yang relatif lama mengharuskan siswi mengikuti segala kegiatan pembelajaran di sekolah yang mengakibatkan aktivitas siswi menjadi padat sehingga berdampak pada kesulitan siswi dalam mengatur waktu istirahat dan pola makannya. Pola makan yang tidak teratur dapat memberikan dampak terhadap status gizi siswi. Penelitian ini dilakukan untuk mengetahui hubungan pola makan dan aktivitas fisik dengan status gizi siswi kelas VII SMP Negeri full day school Kota Malang. Rancangan pada penelitian ini menggunakan metode penelitian korelasional dengan desain penelitian cross sectional. Sampel yang digunakan sebanyak 100 siswi dengan teknik stratified random sampling. Analisis data menggunakan uji korelasi spearman. Hasil dari penelitian ini menunjukkan adanya hubungan yang signifikan antara pola makan dengan status gizi siswi dengan dengan $\mathrm{p}$ value 0,000 dan koefisien korelasi sebesar 0,406.Juga menunjukkan adanya hubungan yang signifikan antara aktivitas fisik dengan status gizi siswi dengan p value 0,000 dan koefisien korelasi sebesar -0,348.
\end{abstract}

Kata Kunci: pola makan, aktivitas fisik, status gizi 


\section{PENDAHULUAN}

Upaya pemerintah dalam meningkatkan mutu pendidikan salah satunya adalah melalui program full day school.Proses belajar mengajar yang diberlakukan pada sistem pembelajaran full day school dimulai pada pagi hari sampai sore hari, mulai pukul 06.45-15.30 WIB. Waktu yang relatif lama mengharuskan siswi mengikuti segala kegiatan pembelajaran di sekolah yang dapat mengakibatkan aktivitas siswi menjadi padat sehingga berdampak pada kesulitan siswi dalam mengatur waktu istirahatnya dan menyebabkan pola makan siswi tidak teratur. Berdasarkan hasil penelitian Palupi (2017) yang dilakukan di MAN Gondanglegi faktor penghambat dalam implementasi program full day school salah satunya yaitu siswa kesulitan dalam mengatur pola makan karena padatnya kegiatan. Pola makan yang tidak teratur dapat memberikan dampak terhadap status gizi siswi, seperti yang dikemukakan Kadir (2016) kebiasaan makan (food habit) dalam suatu kelompok masyarakat akan memberikan dampak pada status gizi masyarakat setempat.

Status gizi remaja merupakan keadaan terpenuhinya kebutuhan terhadap zat gizi, yaitu keseimbangan antara konsumsi dan penyerapan zat gizi. Ketidakseimbangan antara konsumsi dan penyerapan zat gizi dapat menyebabkan masalah gizi seperti gizi lebih ataupun gizi kurang. Hasil Riset Kesehatan Dasar (2013) menunjukkan remaja yang mengalami kelebihan berat badan yaitu 7,8\% pada remaja putra dan 15,5\% pada remaja putri (Kemenkes RI, 2013). Menurut Dinas Kesehatan Kota Malang (2017) persentase obesitas pada remaja usia 15 tahun adalah sebagai berikut: laki-laki $10,72 \%$ dan perempuan 12,37\%.Faktor yang mempengaruhi status gizi salah satunya adalah pola makan. Pola makan merupakan perilaku paling penting yang dapat mempengaruhi keadaan gizi. Pola makan yang baik adalah berpedoman pada Gizi Seimbang (Kemenkes RI, 2014). Proporsi penduduk Indonesia menurut tingkat kecukupan energi tahun 2014 pada kelompok umur 13-18 tahun adalah sangat kurang 52,5\%, kurang 30,3\%, normal 12,2\%, dan lebih 5,0\% Sedangkan menurut jenis kelamin perempuan sangat kurang 46,7\%, kurang 33,4\%, normal 14,1\% dan lebih 5,8\% (Kemenkes RI, 2016b). Faktor lain yang mempengaruhi status gizi remaja adalah aktivitas fisik. Aktivitas fisik diperlukan remaja untuk menjaga berat badan ideal dan kebugaran tubuh (Dieny, 2014). Menurut Kemenkes RI (2012) menyatakan bahwa 48,2\% penduduk Indonesia yang berusia lebih dari 10 tahun kurang melakukan aktivitas fisik, dimana kelompok perempuan yang kurang melakukan aktivitas fisik sebesar 54,5\% lebih tinggi dibanding kelompok laki-laki yaitu sebesar 41,4\%.

Sekolah Menengah Pertama Negeri (SMPN) di Kota Malang merupakan sekolah yang sudah menerapkan sistem pembelajaran full day school. Berdasarkan hasil wawancara yang dilakukan peneliti dengan siswi kelas VII di SMP Negeri 5, SMP Negeri 10, dan SMP Negeri 27 dengan rincian sebanyak 9 siswi dari masingmasing SMP, didapatkan hasil bahwa dengan adanya sistem full day school membuat siswi merasa kelelahan dan bosan akibat proses pembelajaran yang panjang, kegiatan yang padat, dan tugas yang banyak disekolah. Hal tersebut menyebabkan pola makan siswi tidak teratur dan kurangnya waktu istirahat. Penerapan sistem full day school di sekolah membuat kegiatan gerak siswi menjadi minim, proses pembelajaran yang padat membuat siswi harus selalu fokus pada penjelasan guru di dalam kelas dan tuntutan tugas yang harus diselesaikan tepat 
waktu. Dari paparan di atas peneliti ingin mengetahui lebih lanjut Hubungan Pola Makan dan Aktivitas Fisik dengan Status Gizi Siswi Kelas VII SMP Negeri (Full DaySchool)di Kota Malang.

\section{METODE}

Rancangan pada penelitian ini menggunakan metode penelitian korelasional dengan desain penelitian cross sectional. Variabel terikat dalam penelitian ini adalah status gizi, sedangkan variabel bebas adalah pola makan dan aktivitas fisik. Sampel yang digunakan dalam penelitian adalah siswi kelas VII SMP Negeri 5, SMP Negeri 10, dan SMP Negeri 27 Kota Malang sebanyak 100 siswi yang diambil dengan teknik pengambilan sampel stratified random sampling. Data status gizi diperoleh dari pengukuran antropometri berdasarkan IMT/U. Pola konsumsi diperoleh dengan menggunakan Food Frequency Questionnaire (FFQ). Aktivitas fisik responden dalam satu minggu diukur dengan menggunakan PAQ-C (Physical Activity Questionnare for Older Children). Pengolahan data dalam penelitian ini terdiri dari empat tahap yaitu editing, coding, processing dan cleaning. Analisis data yang dilakukan meliputi analisis univariat dan bivariat. Teknik analisis bivariat dalam penelitian ini menggunakan uji korelasi Spearman dengan menggunakan software IBM SPSS Statistics 22.

\section{HASIL}

\section{Distribusi Frekuensi Responden Berdasarkan Umur}

Umur responden berkisar antara 12-14 tahun, berdasarkan sebaran rata-rata umur responden adalah 13 tahun. Distribusi responden berdasarkan umurnya adalah dari 100 responden penelitian, sebanyak 60\% (60 responden) memiliki umur 13 tahun, sebanyak 32\% (32 responden) memiliki umur 12 tahun, dan sebanyak $8 \%$ (8 responden) memiliki umur 14 tahun.

\section{Distribusi Frekuensi Status Gizi Siswi}

Responden dari penelitian ini adalah siswi SMP kelas VII dimana usianya berkisar antara 12 - 14 tahun, sehingga pengukuran status gizi dalam penelitian ini menggunakan acuan Indeks Kemenkes RI 2010 yaitu IMT/U Anak Umur 5 - 18 tahun. Distribusi frekuensi status gizi siswi dapat dilihat pada tabel berikut:

Tabel 1 Distribusi Frekuensi Status Gizi Siswi

\begin{tabular}{ccc}
\hline Kategori & Frekuensi & Persentase (\%) \\
\hline Sangat Kurus & 0 & 0 \\
Kurus & 0 & 0 \\
Normal & 80 & 80 \\
Gemuk & 8 & 8 \\
Obesitas & 12 & 12 \\
\hline Jumlah & 100 & 100 \\
\hline
\end{tabular}

Berdasarkan tabel 1 menunjukkan bahwa dari 100 responden penelitian, sebanyak $80 \%$ ( 80 responden) tergolong dalam status gizi normal, 12\% (12 responden) tergolong dalam status gizi obesitas, $8 \%$ (8 responden) tergolong dalam 
status gemuk, dan tidak ada yang tergolong dalam status gizi kurus dan status gizi sangat kurus.

\section{Distribusi Frekuensi Pola Makan Siswi}

Dalam penelitian ini pola makan diukur dengan instrumen Food Frequency Questionaire (FFQ). Kemudian hasilnya dikategorikan menjadi pola makan kurang, pola makan cukup dan pola makan baik. Kategori baik bila skor 491 - 703, cukup bila skor 278 - 490, dan kurang bila skor $65-277$. Rumus perhitungan skor pola makan adalah sebagai berikut:

\begin{tabular}{|ll|}
\hline Pola Makan & \\
Skor Maks & $=703$ \\
Skor Min & $=65$ \\
Range & $=703-65=638$ \\
Kelas & $=3$ \\
Interval & $=\mathrm{R} / \mathrm{K}=638 / 3=212$ \\
& \\
Baik & $=491-703$ \\
Cukup & $=278-490$ \\
Kurang & $=65-277$ \\
\hline
\end{tabular}
berikut.

Distribusi responden berdasarkan pola makannya dapat dilihat dari grafik Gambar 1 Distribusi Frekuensi Responden Berdasarkan Pola Makan

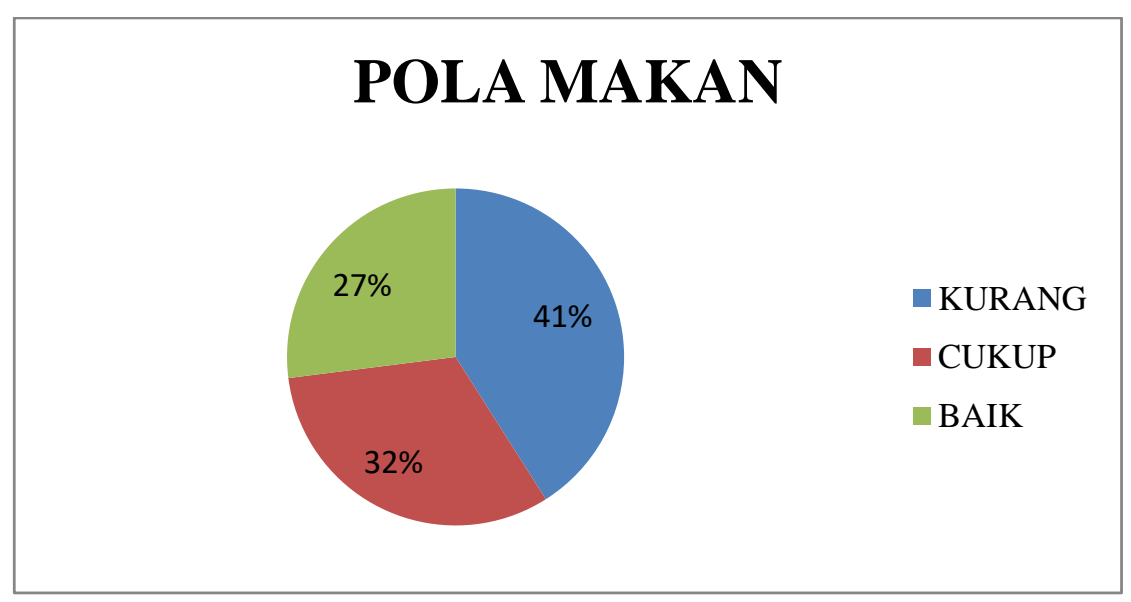

Berdasarkan Gambar 1 menunjukkan bahwa dari 100 responden penelitian, sebanyak $41 \%$ (41 responden) tergolong dalam pola makan kurang, 32\% (32 responden) tergolong dalam pola makan cukup, dan 27\% (27 responden) tergolong dalam pola makan baik. Berikut ini adalah tabel pola konsumsi siswi dilihat dari bahan makanan yang paling banyak dikonsumsi. 
Tabel 2 Distribusi Frekuensi Konsumsi

\begin{tabular}{|c|c|c|c|c|}
\hline \multirow{2}{*}{$\begin{array}{c}\text { Makanan } \\
\text { Pokok }\end{array}$} & \multicolumn{2}{|c|}{ Lauk Pauk } & \multirow[t]{2}{*}{ Sayuran } & \multirow[t]{2}{*}{ Buah-buahan } \\
\hline & Nabati & Hewani & & \\
\hline 1. Nasi & 1. Tempe & 1. Telur & 1. Bayam & 1. Melon \\
\hline 2. Roti & 2. Tahu & 2. Ayam & 2. Kangkung & 2. Jeruk \\
\hline
\end{tabular}

Berdasarkan tabel 2 dapat diketahui frekuensi konsumsi makanan pokok, lauk-pauk, sayur-sayuran dan buah-buahan pada responden paling banyak adalah nasi, roti, tempe, tahu, telur, ayam, bayam, kangkung, melon, dan jeruk.

\section{Distribusi Frekuensi Aktivitas Fisik Siswi}

Aktivitas fisik responden dalam satu minggu diukur dengan menggunakan PAQ-C (Physical Activity Questionnare for Older Children). Kemudian hasilnya dikategorikan menjadi aktivitas fisik sangat rendah, aktivitas fisik rendah, aktivitas fisik sedang, aktivitas fisik tinggi, dan aktivitas fisik sangat tinggi. Distribusi responden berdasarkan aktivitas fisiknya dapat dilihat dari tabel berikut.

Tabel 3 Distribusi Frekuensi Aktivitas Fisik Siswi

\begin{tabular}{ccc}
\hline Kategori & Frekuensi & Persentase (\%) \\
\hline Sangat Rendah & 5 & 5 \\
Rendah & 66 & 66 \\
Sedang & 28 & 28 \\
Tinggi & 1 & 1 \\
Sangat Tinggi & 0 & 0 \\
\hline Jumlah & 100 & 100 \\
\hline
\end{tabular}

Berdasarkan tabel 3 menunjukkan bahwa dari 100 responden penelitian, sebanyak 66\% (66 responden) tergolong dalam aktivitas fisik rendah, 28\% (28 responden) tergolong dalam aktivitas fisik sedang, $5 \%$ (responden) tergolong dalam aktivitas fisik sangat rendah, dan $1 \%$ (1 responden) tergolong dalam aktivitas fisik tinggi.

Tabel 4 Hubungan antara Pola Makan dengan Status Gizi siswi kelas VII SMP Negeri (full day school) Kota Malang

\begin{tabular}{|c|c|c|c|c|c|c|c|c|c|c|}
\hline \multirow{3}{*}{$\begin{array}{c}\text { Status } \\
\text { Gizi }\end{array}$} & \multicolumn{6}{|c|}{ Pola Makan } & \multirow{2}{*}{\multicolumn{2}{|c|}{ Jumlah }} & \multirow{3}{*}{$\begin{array}{c}\text { Koefisien } \\
\text { Korelasi }\end{array}$} & \multirow{3}{*}{$P$ value } \\
\hline & \multicolumn{2}{|c|}{ Kurang } & \multicolumn{2}{|c|}{ Cukup } & \multicolumn{2}{|c|}{ Baik } & & & & \\
\hline & $\mathrm{n}$ & $\%$ & $\mathrm{n}$ & $\%$ & $\mathrm{~N}$ & $\%$ & $\mathrm{n}$ & $\%$ & & \\
\hline $\begin{array}{l}\text { Sangat } \\
\text { Kurus }\end{array}$ & 0 & 0 & 0 & 0 & 0 & 0 & 0 & 0 & & \\
\hline Kurus & 0 & 0 & 0 & 0 & 0 & 0 & 0 & 0 & & \\
\hline Normal & 40 & 50 & 25 & 31 & 15 & 19 & 80 & 100 & 0,406 & 0,000 \\
\hline Gemuk & 0 & 0 & 1 & 12 & 7 & 88 & 8 & 100 & & \\
\hline Obesitas & 1 & 8 & 6 & 50 & 5 & 42 & 12 & 100 & & \\
\hline Jumlah & 41 & 41 & 32 & 32 & 27 & 27 & 100 & 100 & & \\
\hline
\end{tabular}

Berdasarkan tabel 4 diperoleh nilai $\mathrm{P}$ value $=0,000$, maka dapat disimpulkan bahwa terdapathubungan yang bermakna antara pola makan dengan status gizi siswi kelas VII SMPN Negeri (full day school)Kota Malang. Sedangkan 
nilai koefisien korelasi $\mathrm{r}=0,406$ yang dapat diartikan bahwa hubungan antara pola makan dengan status gizi tergolong cukup dengan arah korelasi positif, sehingga hubungan kedua variabel tersebut bersifat searah. Hubungan antara pola makan dengan status gizi terlihat bahwa semakin baik pola makan siswi maka semakin besar kemungkinan untuk memiliki status gizi normal.

Tabel 5 Hubungan antara Aktivitas Fisik dengan Status Gizi siswi kelas VII SMP Negeri (full day school) Kota Malang

\begin{tabular}{|c|c|c|c|c|c|c|c|c|c|c|c|c|c|c|}
\hline \multirow{3}{*}{$\begin{array}{c}\text { Status } \\
\text { Gizi }\end{array}$} & \multicolumn{10}{|c|}{ Aktivitas Fisik } & \multirow{2}{*}{\multicolumn{2}{|c|}{ JML }} & \multirow{3}{*}{$\begin{array}{c}\text { Koef. } \\
\text { Korela } \\
\text { si }\end{array}$} & \multirow{3}{*}{$\begin{array}{c}\mathbf{P} \\
\text { value }\end{array}$} \\
\hline & \multicolumn{2}{|c|}{$\begin{array}{l}\text { Sangat } \\
\text { Rendah }\end{array}$} & \multicolumn{2}{|c|}{ Rendah } & \multicolumn{2}{|c|}{ sedang } & \multicolumn{2}{|c|}{ Tinggi } & \multicolumn{2}{|c|}{$\begin{array}{c}\text { Sangat } \\
\text { Tinggi }\end{array}$} & & & & \\
\hline & $\mathrm{n}$ & $\%$ & $\mathrm{n}$ & $\%$ & $\mathrm{~N}$ & $\%$ & $\mathrm{n}$ & $\%$ & $\mathrm{~N}$ & $\%$ & $\mathrm{n}$ & $\%$ & & \\
\hline $\begin{array}{l}\text { Sangat } \\
\text { Kurus }\end{array}$ & 0 & 0 & 0 & 0 & 0 & 0 & 0 & 0 & 0 & 0 & 0 & 0 & & \\
\hline Kurus & 0 & 0 & 0 & 0 & 0 & 0 & 0 & 0 & 0 & 0 & 0 & 0 & & \\
\hline $\begin{array}{l}\text { Nor- } \\
\text { mal }\end{array}$ & 1 & 1 & 51 & 64 & 27 & 34 & 1 & 1 & 0 & 0 & 80 & 100 & $-0,348$ & 0,000 \\
\hline Gemuk & 1 & 12 & 7 & 88 & 0 & 0 & 0 & 0 & 0 & 0 & 8 & 100 & & \\
\hline $\begin{array}{l}\text { Obe- } \\
\text { sitas }\end{array}$ & 3 & 25 & 8 & 67 & 1 & 8 & 0 & 0 & 0 & 0 & 12 & 100 & & \\
\hline JML & 5 & 5 & 66 & 66 & 28 & 28 & 1 & 1 & 0 & 0 & 100 & 100 & & \\
\hline
\end{tabular}

Berdasarkan tabel 5 diperoleh nilai $\mathrm{P}$ value $=0,000$, maka dapat disimpulkan bahwa terdapathubungan yang bermakna antara aktivitas fisik dengan status gizi siswi kelas VII SMPN Negeri (full day school)Kota Malang. Sedangkan nilai koefisien korelasi $\mathrm{r}=-0,348$ yang dapat diartikan bahwa hubungan antara aktivitas fisik dengan status gizi tergolong cukup dengan arah korelasi negatif, sehingga hubungan kedua variabel tersebut bersifat tidak searah yang berarti semakin rendah intensitas aktivitas fisik yang dilakukan maka berpengaruh terhadap status gizi (IMT/U) gemuk bahkan obesitas.

\section{PEMBAHASAN}

\section{Gambaran Status Gizi Siswi}

Hasil penelitian menunjukkan mayoritas siswi kelas VII SMP Negeri full day school memiliki status gizi normal dengan persentase $80 \%$. Status gizi yang normal dapat terjadi apabila tubuh cukup memperoleh zat-zat gizi yang digunakan secara efisien, sehingga memungkinkan pertumbuhan fisik, perkembangan otak, kemampuan kerja mencapai tingkat optimal (Syahfitri, Ernalia, \& Restuastuti, 2017). Namun masih ada yang memiliki status gizi gemuk $8 \%$ dan obesitas $12 \%$. Prevalensi status gizi gemuk berada dibawah angka nasional sedangkan prevalensi status gizi obesitas berada diatas angka nasional jika dibandingkan dengan hasil Riskesdas 2013 yang menunjukkan secara nasional prevalensi gemuk pada remaja usia 13-15 tahun sebesar $10.8 \%$, terdiri dari 8,3\% gemuk dan 2,5\% sangat gemuk (obesitas). Sedangkan jika dibandingkan dengan hasil Pemantauan Status Gizi di Indonesia tahun 2016 menunjukkan secara nasional prevalensi gemuk pada remaja putri usia 12-18 tahun dibawah angka nasional yaitu sebesar 15,1\% dan angka obesitas diatas angka nasional sebesar 4,3\% (Kemenkes RI, 2016). 
Faktor yang menyebabkan siswi dengan status gizi gemuk dan obesitas dikarenakan terlalu banyak mengkonsumsi karbohidrat, lemak, maupun protein, 
dan juga karena kurang melakukan aktivitas fisik (Florence, 2017). Status gizi lebih terjadi bila tubuh memperoleh zat-zat gizi dalam jumlah yang berlebihan sehingga dapat menimbulkan efek toksis atau membahayakan (Istiany, 2014). Nurcahyo (2011) menyatakan bahwa anak-anak yang memiliki berat tubuh berlebihan atau mengalami kegemukan (obesitas) biasanya memiliki kebiasaan ngemil yang tinggi (makan-makanan ringan), banyak menyendiri, banyak berdiam diri di kamar/di rumah, mudah dan lebih banyak tidur, sehingga kurang atau bahkan tidak suka beraktivitas jasmani dan berolahraga (fisik). Anak yang mengalami obesitas selain keterampilan geraknya akan cenderung kaku, tidak lincah hal tersebut disebabkan oleh jumlah kalori yang masuk dan energi yang dikeluarkan tidak seimbang sehingga terjadinya obesitas pada anak.

\section{Gambaran Pola Makan Siswi}

Berdasarkan hasil penelitian menunjukkan bahwa dari 100 responden sebanyak $41 \%$ (41 responden) tergolong dalam pola makan kurang, 32\% (32 responden) tergolong dalam pola makan cukup, dan $27 \%$ (27 responden) tergolong dalam pola makan baik. Pola makan responden tertinggi adalah yang berkategori kurang sebesar $41 \%$, angka yang tinggi disebabkan karena waktu siswi yang padat dan lebih lama di sekolah serta tugas-tugas yang harus diselesaikan tepat waktu sehingga membuat siswi sering melewatkan waktu makan akibatnya membuat pola makan siswi tidak teratur. Berdasarkan hasil wawancara dengan beberapa siswi mengatakan bahwa dalam sehari siswi hanya makan satu kali sampai dua kali karena padatnya dan lamanya waktu yang dihabiskan disekolah.

\section{Gambaran Aktivitas Fisik Siswi}

Berdasarkan hasil penelitian menunjukkan bahwa dari 100 responden penelitian, sebanyak 66\% (66 responden) tergolong dalam aktivitas fisik rendah, $28 \%$ (28 responden) tergolong dalam aktivitas fisik sedang, 5\% (responden) tergolong dalam aktivitas fisik sangat rendah, dan $1 \%$ ( 1 responden) tergolong dalam aktivitas fisik tinggi. Jumlah tertinggi adalah siswi yang tergolong dalam aktivitas fisik rendah, angka yang tinggi disebabkan oleh kurangnya aktivitas jasmani atau olahraga yang dilakukan siswi. Penerapan sistem full day school di sekolah membuat kegiatan gerak siswi menjadi minim, proses pembelajaran yang padat membuat siswi harus selalu fokus pada penjelasan guru di dalam kelas dan tuntutan tugas yang harus diselesaikan tepat waktu. Akibatnya siswi merasa kelelahan dan bosan sehingga menyebabkan siswi malas untuk melakukan aktivitas fisik atau berolahraga sendiri dirumah maupun di sekolah.Hal tersebut juga didukung oleh hasil kuisioner yang diisi oleh siswi.

\section{Hubungan Pola Makan dengan Status Gizi Siswi}

Hasil statistik menunjukkan terdapathubungan yang bermakna antara pola makan dengan status gizi siswi kelas VII SMPN Negeri (full day school)Kota Malangdengan nilai $\mathrm{P}$ value $0,000<0,05$ dan nilai koefisien korelasi $r=0,406$ yang dapat diartikan bahwa hubungan antara pola makan dengan status gizi tergolong cukup dengan arah korelasi positif, sehingga hubungan kedua variabel tersebut bersifat searah. Hubungan antara pola makan dengan status gizi terlihat bahwa semakin baik pola makan siswi maka semakin besar kemungkinan untuk memiliki status gizi normal. Hal tersebut juga sejalan dengan penelitian yang dilakukan 
(Afrilia \& Festilia, 2018) Berdasarkan hasil uji statistik dengan menggunakan chisquare test menunjukkan adanya hubungan antara pola makan terhadap status gizi $(\mathrm{p}=0,016<0,05)$. Selain itu, siswa yang berstatus gizi kurang lebih besar terdapat pada siswa yang pola makannya kurang yaitu sebesar $(18,5 \%)$.

Berdasarkan hasil penelitian dari 80 siswi yang memiliki status gizi normal sebanyak 40 siswi memiliki pola makan kurang, pola makan yang kurang pada siswi dengan status gizi normal dapat disebabkan karena waktu siswi yang padat sehingga siswi hanya dapat makan satu kali sehari dengan porsi makan dalam jumlah besar dalam setiap kali makan, maka tidak menutup kemungkinan siswi tersebut memiliki status gizi normal. Berdasarkan hasil wawancara dengan sebagian responden mengatakan bahwa dalam sehari hanya makan satu kali hingga dua kali saja dan jarang bahkan tidak pernah sarapan jika akan berangkat ke sekolah. Hal tersebut dikarenakan waktu sekolah yang lebih panjang yang mengharuskan siswi berangkat lebih pagi dan pulang sore hari.

Berdasarkan hasil penelitian sebanyak 8 siswi yang memiliki status gizi gemuk, 7 siswi memiliki pola makan baik dan 1 siswi memiliki pola makan yang cukup.Sedangkan dari 12 siswi yang memiliki status gizi obesitas sebanyak 6 siswi memiliki pola makan cukup dan 5 siswi memiliki pola makan baik. Pola makan baik tidak menutup kemungkinan siswi mempunyai status gizi lebih dalam hal ini gemuk maupun obesitas. Jika frekuensi pola makan terlihat baik namun porsi, jumlah dan berat makanan yang dikonsumsi berlebihan akan menyebabkan status gizi lebih yaitu gemuk dan obesitas.

Faktor yang mempengaruhi status gizi salah satunya adalah pola makan. Pola makan merupakan perilaku paling penting yang dapat mempengaruhi keadaan gizi. Pola makan yang baik adalah berpedoman pada Gizi Seimbang (Kemenkes, 2014). Remaja awal yang dikategorikan sebagai siswa Sekolah Menengah Pertama (SMP), dimana kegiatan sudah banyak dan dengan konsumsi yang tidak terkontrol penuh oleh orang tua. Status gizi merupakan hal penting yang harus diketahui oleh setiap individu supaya mampu mengantisipasi dan mencegah terjadinya gizi kurang maupun gizi lebih (Syahfitri, 2016). Proporsi penduduk Indonesia menurut tingkat kecukupan energi tahun 2014 pada kelompok umur 13-18 tahun adalah sangat kurang 52,5\%, kurang 30,3\%, normal 12,2\%, dan lebih 5,0\% (Kemenkes RI, 2016). Sedangkan menurut jenis kelamin perempuan sangat kurang 46,7\%, kurang 33,4\%, normal 14,1\% dan lebih 5,8\% (Kemenkes RI, 2016).

Kebiasaan makan yang sering terlihat pada remaja antara lain makan cemilan, melewatkan waktu makan terutama sarapan pagi, waktu makan tidak teratur, sering makan fast food, jarang mengkonsumsi sayur, buah dan ataupun produk peternakan (dairy food) serta pengontrolan berat badan yang salah pada remaja putri. Hal tersebut dapat mengakibatkan asupan makanan tidak sesuai kebutuhan dan gizi seimbang dengan akibatnya gizi kurang atau lebih (Irianto, 2016). Berdasarkan hasil wawancara yang dilakukan peneliti dengan siswi kelas VII di SMP Negeri 5, SMP Negeri 10, dan SMP Negeri 27 dengan rincian sebanyak 9 siswi dari masing-masing SMP di atas, didapatkan hasil bahwa dengan adanya sistem full day school yang diterapkan di sekolah membuat siswi merasa kelelahan dan bosan akibat proses pembelajaran yang panjang, kegiatan yang padat, dan tugas yang banyak disekolah. Proses pembelajaran yang panjang, kegiatan yang padat, dan tugas yang banyak menyebabkan pola makan siswi tidak teratur, siswi sering kali melewatkan waktu sarapan dan lebih memilih membeli makanan yang 
disediakan dikantin sekolah. Di masing-masing sekolah yang menjadi tempat penelitian semua menyediakan kantin sekolah, dua diantara ketiga sekolah tersebut yaitu SMP Negeri 5 dan SMP Negeri 10 menerapkan kantin sehat. Yaitu kantin yang menjual makanan yang sehat dan aman dari cemaran fisik, biologis, dan zat kimia yang berbahaya. Akan tetapi, waktu istirahat siswi lebih sering digunakan untuk menyelesaikan tugas yang diberikan guru. Berdasarkan hasil wawancara beberapa siswi mengatakan lebih sering melewatkan waktu makan di waktu istirahat karena tugas yang banyak yang harus diselesaikan saat itu juga.

\section{Hubungan Aktivitas Fisik dengan Status Gizi Siswi}

Terdapat hubungan yang bermakna antara aktivitas fisik dengan status gizi siswi kelas VII SMPN Negeri (full day school)Kota Malang dengan nilai P value $0,000<0,05$ dan nilai koefisien korelasi $\mathrm{r}=-0,348$ yang dapat diartikan bahwa hubungan antara aktivitas fisik dengan status gizi tergolong cukup dengan arah korelasi negatif, sehingga hubungan kedua variabel tersebut bersifat tidak searah yang berarti semakin rendah intensitas aktivitas fisik yang dilakukan maka berpengaruh terhadap status gizi (IMT/U) gemuk bahkan obesitas. Hal tersebut sejalan dengan penelitian yang dilakukan Khasanah tahun 2016. Hasil uji analitik diperoleh ada hubungan aktivitas fisik dengan status gizi remaja putri di Pondok Pesantren Ta'mirul Islam Surakarta. Kesimpulan ada hubungan aktivitas fisik dengan status gizi remaja dengan nilai $(\mathrm{p}=0,005)$ pada remaja putri di Pondok Pesantren Ta'mirul Islam Surakarta.

Faktor yang mempengaruhi status gizi remaja salah satunya adalah aktivitas fisik. Aktivitas fisik diperlukan remaja untuk menjaga berat badan ideal dan kebugaran tubuh (Dieny, 2014). Aktivitas fisik merupakan salah satu penyebab yang memengaruhikeadaan status gizi seseorang. Aktivitas fisik yang ringan akanmenyebabkan status gizinya menjadi obesitas atau overweight. Hal ini dikarenakan banyaknya energi yang tertumpuk di dalam tubuhdikarenakan tidak adanya pembakaran kalori ditubuh karena aktivitasnya yangtidak cukup(Serly, Sofian, \& Ernalia, 2015). Menurut (Condello et al., 2016) kombinasi aktivitas fisik yang tidak mencukupi dan asupan energi yang tinggi bertanggungjawab atas kelebihan berat badan dan obesitas. Semakin aktif seseorang dalam melakukan aktivias fisik maka semakin banyak energi yang dikeluarkan, jika asupan energiberlebih tanpa diimbangi aktivitas fisik yang seimbang maka remaja mudahmengalami kelebihan berat badan (Khasanah, 2016).

Pada penelitian ini didapatkan hasil mayoritas siswi memiliki aktivitas fisik rendah sebesar 66\%. Hal ini sejalan dengan data Kemenkes RI (2012) yang menyatakan bahwa 48,2\% penduduk Indonesia yang berusia lebih dari 10 tahun kurang melakukan aktivitas fisik, dimana kelompok perempuan yang kurang melakukan aktivitas fisik sebesar 54,5\% lebih tinggi dibanding kelompok laki-laki yaitu sebesar 41,4\%. Berdasarkan hasil penelitian dari 80 siswi yang memiliki status gizi normal sebanyak 51 siswi memiliki aktivitas fisik rendah, hal ini bisa dikarenakan berbagai faktor yaitu karena penelitian ini dilakukan hanya diambil 7 hari kemungkinan dalam waktu tersebut ternyata aktivitas siswi memang ringan atau rendah tetapi dihari-hari sebelumnya aktivitasnya termasuk sedang atau tinggi, atau bisa juga dikarenakan pola makan yang kurang dari responden sehingga walaupun aktivitas fisiknya rendah karena pola makan juga kurang akan menyebabkan status gizinya menjadi normal. 


\section{SIMPULAN}

Berdasakan hasil penelitian yang telah dipaparkan, maka dapat diambil kesimpulan bahwastatus gizi siswi kelas VII SMP Negeri (Full Day School)tertinggi adalah berkategori normal. Pola makan siswi tertinggi adalah yang berkategori kurang. Dan aktivitas fisik siswi tertinggi adalah yang berkategori rendah. Juga didapatkan hasil ada hubungan yang signifikan antara pola makan dengan status gizi siswi kelas VII SMP Negeri (Full Day School) Kota Malang dan ada hubungan yang signifikan antara aktivitas fisik dengan status gizi siswi kelas VII SMP Negeri (Full Day School) Kota Malang.

\section{SARAN}

Saran yang dapat diberikan bagi siswi adalah siswi diharapkan untuk memperhatikan pola makan dan membiasakan aktivitas fisik rutin setiap hari. Saran yang dapat diberikan kepada peneliti selanjutnya adalah perlu dilakukan penelitian lanjutan tentang faktor lain yang tidak diteliti dalam penelitian ini juga disarankan untuk melanjutkan penelitian pola makan dengan menggunakan instrumen food recall $24 \mathrm{jam}$.

\section{DAFTAR PUSTAKA}

Kadir, Abdul. (2016). Kebiasaan Makan dan Gangguan Pola Makan serta Pengaruhnya terhadap Status Gizi Remaja. Jurnal Publikasi Pendidikan, VI(1), 49-55.

Afrilia, D. A., \& Festilia, S. (2018). Hubungan Pola Makan dan Aktifitas Fisik Terhadap Status Gizi di Siswa SMP Jurusan Gizi , Poltekkes Kemenkes Pontianak , Indonesia, 01(01).

Condello, G., Capranica, L., Stager, J., Forte, R., Falbo, S., Di Baldassarre, A., ... Pesce, C. (2016). Physical activity and health perception in aging: Do body mass and satisfaction matter? A three-path mediated link. PLOS ONE, 11(9). https://doi.org/10.1371/journal.pone.0160805

Dieny, F. (2014). Permasalahan pada Remaja Putri. Graha Ilmu.

Dinas Kesehatan Kota Malang. (2017). Profil Kesehatan Kota Malang Tahun 2017.

Florence, A. (2017). Hubungan Pengetahuan Gizi Dengan Status Gizi Pada Mahasiswa TPB Sekolah Bisnis Dan Manajemen Institut Teknologi Bandung. Skripsi, 1-133.

Irianto, D. P. (2016). Pedoman Gizi Lengkap Keluarga \& Olahragawan. ANDI.

Istiany., R. (2014). Gizi Terapan. PT REMAJA ROSDAKAYA.

Kemenkes RI. (2012). Strategi Nasional Penerapan Pola Konsumsi Makanan dan Aktivitas Fisik Untuk Mencegah Penyakit Tidak Menular. Diambil dari http://gizi.depkes.go.id/download/Pedoman Gizi/STRANAS kt penganta.pdfgabung.pdf

Kemenkes RI. (2013). Riskesdas 2013. Diambil dari www.depkes.go.id/resources/download/general/Hasil Riskesdas 2013.pdf

Kemenkes RI. (2014). Pedoman Gizi Seimbang 2014. Diambil dari http://gizi.depkes.go.id/pgs-2014-2

Kemenkes RI. (2016a). Hasil Penentuan Status Gizi dan Penjelasannya. Diambil 
dari http://www.kesmas.kemkes.go.id/assets/upload/dir_519d41d8cd98f00/files/Buku-Saku-Hasil-PSG-2016_842.pdf

Kemenkes RI. (2016b). Situasi Gizi, 43.

Khasanah, D. (2016). Hubungan Aktivitas Fisik Dengan Status Gizi Remaja Putri Di Pondok Pesantren Ta'Mirul Islam Surakarta Publikasi Ilmiah.

Nurcahyo, F. (2011). Kaitan antara Obesitas dan Aktivitas Fisik. Medikora, VII(April), 87-96. Diambil dari https://journal.uny.ac.id/index.php/medikora/article/viewFile/4663/4012

Palupi, N. (2017). Implementasi Full Day School dalam Internalisasi Nilai Moral Siswa pada Mata Pelajaran Aqidah Akhlak di MAN 1 Gondanglegi Kabupaten Malang.

Serly, V., Sofian, A., \& Ernalia, Y. (2015). Hubungan Body Image, Asupan Energi Dan Aktivitas Fisik Dengan Status Gizi Pada Mahasiswa Fakultas Kedokteran Universitas Riau Angkatan 2014. Jurnal Online Mahasiswa (JOM) Bidang Kedokteran, 2(2), 1-14. Diambil dari https://jom.unri.ac.id/index.php/JOMFDOK/article/view/4860

Syahfitri, Y., Ernalia, Y., \& Restuastuti, T. (2017). Gambaran Status Gizi SiswaSiswi SMP Negeri 13 Pekanbaru Tahun 2016. Jom Fk, 4(1), 1-12. Diambil dari https://media.neliti.com/media/publications/184062-ID-gambaran-statusgizi-siswa-siswi-smp-neg.pdf 